Mirosław Włodarczyk

Społeczna Wyższa Szkoła Przedsiębiorczości i Zarządzania w Łodzi

Jerzy Janczewski

Zespół Szkół w Żychlinie

\title{
Wiedza w rozwoju przedsiębiorczości w małym warsztacie samochodowym
}

Kwestie związane z małymi warsztatami samochodowymi w Polsce, podobnie jak dotyczące mikroprzedsiębiorstw i małych przedsiębiorstw, nabierają coraz większego znaczenia ze względu na wzrastający udział sektora usług w gospodarce narodowej. W sektorze usług świadczonych przez mikroprzedsiębiorstwa jedną z bardziej interesujących branż w Polsce są usługi samochodowe. W branży znaczącą grupę przedsiębiorstw stanowią małe warsztaty samochodowe, których liczbę określa się na około 19 tys. ${ }^{1}$ Pod pojęciem małego warsztatu rozumie się przedsiębiorstwo, które zajmuje się obsługą i naprawą samochodów, dysponuje co najmniej jednym stanowiskiem wyposażonym w niezbędne narzędzia i zatrudnia łącznie z właścicielem nie więcej niż dziesięć osób. Takie warsztaty stanowią zdecydowaną większość wśród firm serwisujących samochody w Polsce.

Mimo niewystarczającego poziomu organizacyjnego i technicznego, małe warsztaty motoryzacyjne obsługujące i naprawiające samochody zajmują istotną i stale rosnącą pozycję w branży serwisowania samochodów w porównaniu z dużymi warsztatami i autoryzowanymi stacjami obsługi. Wzrost zapotrzebowania na usługi naprawcze i serwisowanie pojazdów można uzasadnić wieloma czynnikami, z których najistotniejszy jest przyrost liczby samochodów w ostatnich latach, a zwłaszcza samochodów używanych wymagających naprawy. Wzrastająca aktywność gospodarcza małych warsztatów samochodowych jest zjawiskiem stosunkowo nowym, a jej przyczyny nie są dostatecznie rozpoznane. Aktywność przejawia się zapotrzebowaniem na nową wiedzę i - tym samym - na rozwój przedsiębiorczości.

\section{Definicja przedsiębiorczości małego warsztatu samochodowego}

Etymologia słowa ,przedsiębiorczość” wskazuje, że jego źródłem jest wyraz ,przedsiębiorca”. Posiłkując się opracowaniem amerykańskiej organizacji NCOE, zajmującej się przedsiębiorczością, można przyjąć, że pierwsze historyczne określenie przedsiębiorcy powstało w XV w. we Francji. Johannes Gutenberg, wynalazca druku, zasłynął tam ze swych przedsiębiorczych działań. W praktyce tematyka przedsiębiorczości i osoby przedsiębiorcy pojawiała się znacznie wcześniej.

Pojęcie ,przedsiębiorca” zostało wprowadzone do teorii ekonomii przez Richarda Cantillona w XVIII w. Określało ono ,człowieka, który nabywa środki produkcji i wykorzystuje je do wytwarzania wprowadzonych na rynek produktów” (Czaja 1999). Definicja słowa „przedsiębiorca”

\footnotetext{
${ }^{1}$ Dane szacunkowe.
} 
i określenie jego działalności ulegały zmianom. Poszukiwano odpowiedzi na pytanie: kim jest przedsiębiorca?, podając jego szczególne cechy (Bławat 2003). Najbardziej współczesna w XXI w. wydaje się definicja przedsiębiorcy zaproponowana przez Josepha Schumpetera².

Definicja przedsiębiorczości małego warsztatu samochodowego - mikroprzedsiębiorstwa - powinna dotyczyć działań jego właściciela. Przedsiębiorczość takiej firmy to zespół cech opartych na umiejętności kreowania nowych wartości, możliwych do uzyskania przez mikroprzedsiębiorstwo. Cechy te można sklasyfikować następująco:

- umiejętność oceny szans na uruchomienie i rozwój przedsięwzięcia w warunkach turbulentnych;

- umiejętność wykorzystania specyficznych zdolności przedsiębiorcy - właściciela małego warsztatu samochodowego;

- umiejętność zdobywania i wykorzystywania wiedzy oraz doświadczeń przedsiębiorcy i pracowników, opartych na tradycjach i wzorcach zachowań.

Szczególny wpływ na rozwój małych warsztatów samochodowych ma przedsiębiorczość utożsamiana z umiejętnością zdobywania i wykorzystywania informacji oraz doświadczeń przedsiębiorcy i pracowników, dzięki którym odpowiedziały one na dynamiczny wzrost zapotrzebowania na usługi naprawcze. Podstawowe pytania brzmią: Czy w analizie procesów rozwoju małych warsztatów samochodowych zaliczanych do mikroprzedsiębiorstw wiedza przedsiębiorcy i pracowników jest najważniejszym wyznacznikiem? Jak to wygląda w praktyce? Ten problem zostanie rozpatrzony na gruncie przedsiębiorczości odniesionej do mikroprzedsiębiorstw poprzez identyfikacjęjej przejawów.

\section{Wiedza i doświadczenie w małym warsztacie samochodowym}

W zależności od kryterium definiowania przedsiębiorczości (Janczewski 2005), można zaproponować metodę pomiaru i dokonać oceny przedsiębiorczości. Zdobywanie wiedzy jest istotnym kryterium przedsiębiorczości każdej firmy, także i małego warsztatu samochodowego. Wiedza jest najważniejszym elementem procesu obsługi i naprawy samochodów (Cichoń 2005). Odpowiedni poziom wiedzy jest niezbędny do posługiwania się nowymi narzędziami i technologiami w naprawie nowoczesnych modeli samochodów.

Stosunkowo niedawno do poprawnej naprawy wystarczała znajomość budowy i zasad działania zespołów pojazdów oraz podstawowa wiedza z zakresu napraw mechanicznych i elektrycznych. Obecnie, aby zrozumieć budowę i funkcjonowanie większości zespołów, trzeba być również fachowcem w dziedzinie elektroniki. Ponadto należy brać pod uwagę złożoność urządzeń naprawczo-diagnostycznych i trzeba je dokładnie znać, by w pełni wykorzystać ich możliwości. Nawet absolwenci wyższych uczelni technicznych muszą nieustannie aktualizować swoje kwalifikacje. W warsztacie niezbędna jest również wiedza $\mathrm{z}$ dziedziny zarządzania. $\mathrm{W}$ dobrze zarządzanym warsztacie powinno się przewidzieć czas i zakres szkoleń doskonalących umiejętności pracowników. Umiejętności wyróżniające mały warsztat w otoczeniu to przede wszystkim rezultat wykształcenia i wiedzy właściciela i pracowników.

2 J. Schumpeter w pracy Teoria rozwoju gospodarczego przedstawił przełomową koncepcję przedsiębiorcy będącego siłą sprawczą rozwoju gospodarczego i dostrzegł w przedsiębiorcy jego dynamizm i innowacyjność, cechy, dzięki którym uruchamia on nowe przedsiębiorstwa, tworzy nowe wartości: miejsca pracy, nowe produkty, nowe sposoby produkcji, zarządzania, poszukuje nowych rynków zbytu i zaopatrzenia. 
Częstotliwość i formy dokształcania się przedsiębiorcy/menedżera i pracowników serwisu stanowią miernik przedsiębiorczości, który można wyrazić nakładami firmy na szkolenie i doskonalenie zawodowe. Mali przedsiębiorcy muszą zajmować się wszystkimi sprawami swych firm, nie dysponują wolnym czasem na dokształcanie, często nie doceniają tego, że ich wiedza jest kapitałem firmy. Problem zdobywania podstawowych informacji i dokształcania się może być częściowo rozwiązany za pomocą internetu. Dlatego do kryteriów oceny przedsiębiorczości warsztatów samochodowych należy także zaliczyć wykorzystanie komputera. Miernikiem przedsiębiorczości będzie wówczas nie tylko używanie komputera do celów księgowych i administracyjnych, ale przede wszystkim korzystanie z zasobów internetu.

Z badań przeprowadzonych przez autorów tego artykułu w latach 2004 i 2005 na próbie 100 małych warsztatów samochodowych z subregionu płockiego wynika (ryc. 1), że 28\% małych warsztatów nie było nastawionych na podnoszenie kwalifikacji. Dowodzi to, że w sektorze napraw samochodów mogą być jeszcze tacy, którzy korzystają tylko z nabytej kiedyś wiedzy i nie widzą potrzeby stałego jej aktualizowania.

Ryc. 1. Nastawienie warsztatów na podwyższanie kwalifikacji

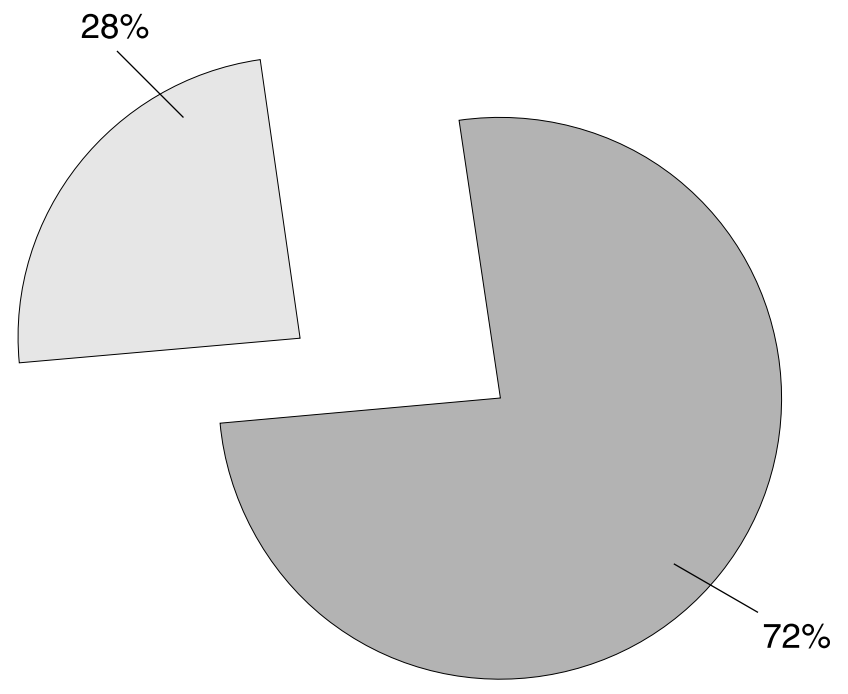

warsztaty zainteresowane podnoszeniem kwalifikacji

warsztaty niezabiegające o podwyższanie kwalifikacji

Źródło: opracowanie autorów na podstawie badań.

Głębsze badanie (ryc. 2) wykazało, że większość (52\%) właścicieli i pracowników małych warsztatów samochodowych dokształcała się sporadycznie, szczególnie wtedy, gdy zmuszała ich do tego konieczność, np. brak informacji o budowie, zamiennikach lub danych regulacyjnych niezbędnych przy naprawach i obsłudze samochodu. Pozostałe małe warsztaty przywiązywały dużą wagę do dokształcania się - 35\% czyniło to systematycznie, a 13\% nastawionych było na stałe uczenie się. Wyniki tych badań są częściowo zbieżne z wynikami badań GIPA, według których tylko 27\% warsztatów niezależnych zaliczało szkolenia techniczne, a handlowe jeszcze mniej - zaledwie 8\%. Najmniej ze szkoleń korzystały warsztaty małe, jednostanowiskowe. Odmienna sytuacja panowała w warsztatach autoryzowanych, z których aż 83\% zaliczało szkolenia techniczne, a 70\% - szkolenia handlowe. 
Ryc. 2. Częstotliwość dokształcania personelu małych warsztatów
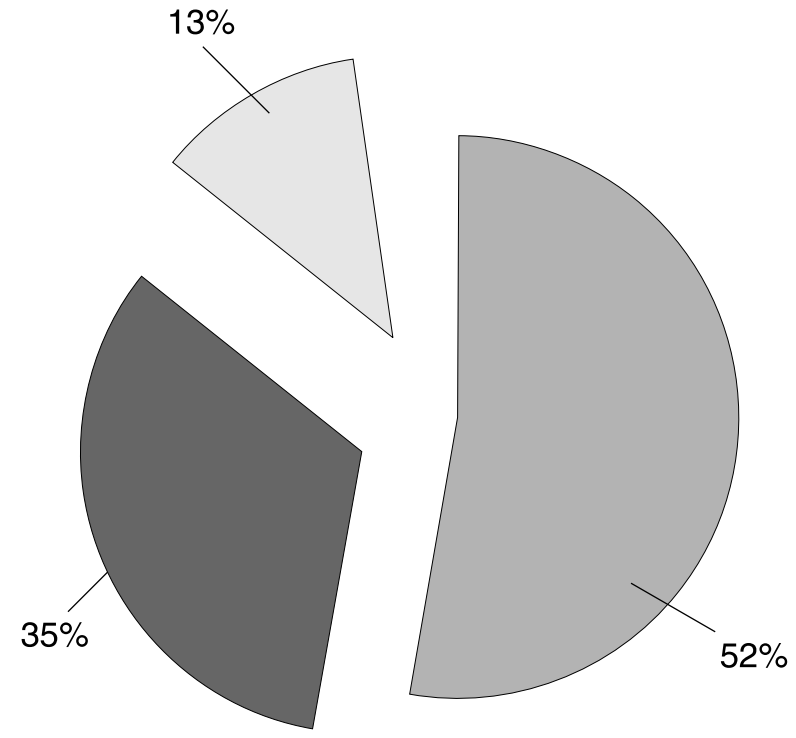

sporadycznie, gdy zachodzi konieczność

systematycznie śledzi dostępne publikacje fachowe

nastawiony jest na różnorodne formy zdobywania wiedzy

Źródło: opracowanie autorów na podstawie badań.

Ryc. 3. Wydatki małych warsztatów na dokształcanie
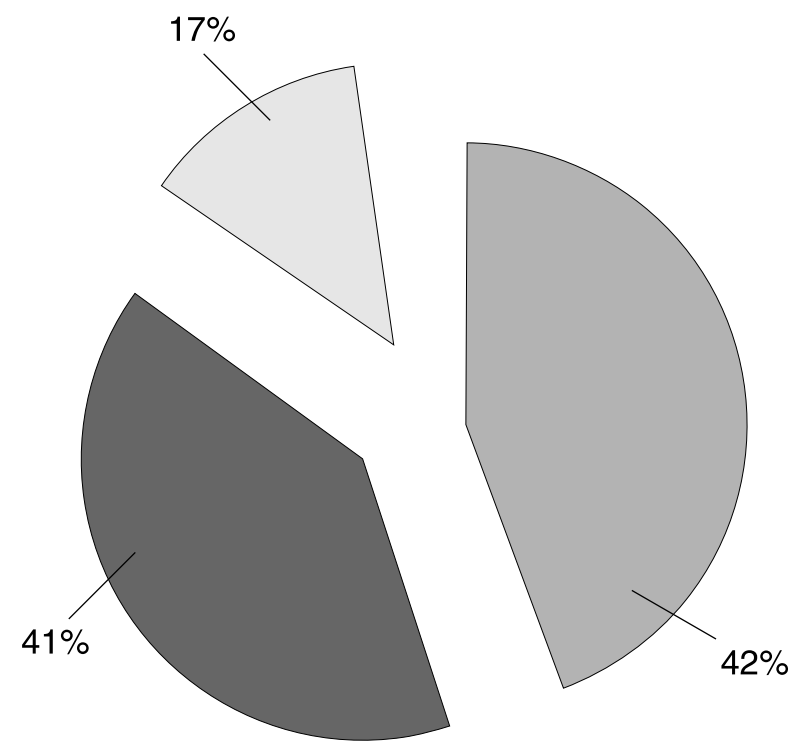

warsztat unika wydatków na dokształcanie

warsztat oszczędza na zdobywaniu wiedzy, wydatki niewielkie

warsztat planuje w budżecie określony procent dochodu na zdobywanie wiedzy

Źródło: opracowanie autorów na podstawie badań.

Zdobywanie wiedzy jest ściśle związane $\mathrm{z}$ wydatkami na ten cel. Z badań autorów tego artykułu wynika (ryc. 3), że 42\% małych warsztatów unikało wydatków na dokształcanie. Zapewne ich właściciele nie korzystali systematycznie z podstawowej prasy fachowej. Podobny odsetek warsztatów (41\%) przeznaczał niewielkie kwoty na dokształcanie się, ale - jak zaznaczyli respondenci - oszczędzają na takich wydatkach. Jedynie $17 \%$ badanych deklarowało, że przeznacza pewien ułamek dochodu na dokształcanie. 
Ryc. 4. Formy dokształcania się personelu małych warsztatów

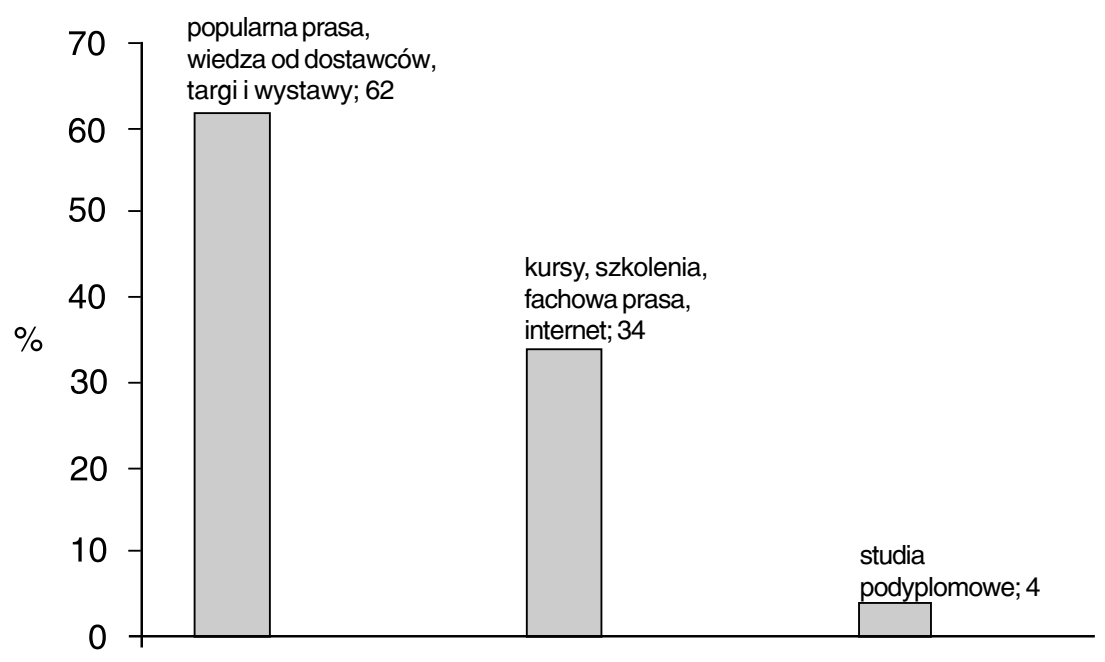

Źródło: opracowanie autorów na podstawie badań.

Zdecydowana większość (62\%) warsztatów zdobywała informacje z popularnej prasy, z instrukcji, ulotek reklamowych lub od dostawców i kolegów z branży. Tylko 4\% personelu warsztatów uczęszczało na studia podyplomowe, pozostali (34\%) studiowali literaturę fachową, brali udział w szkoleniach i korzystali z zasobów internetu (ryc. 4). Internet i komputer w każdej firmie są niezbędnymi narzędziami wspomagającymi jej funkcjonowanie. Fakt właściwego i logicznego wykorzystania możliwości IT powoduje, że stanowi ono powszechne już kryterium oceny przedsiębiorczości.

Ryc. 5. Warsztaty korzystające z komputera

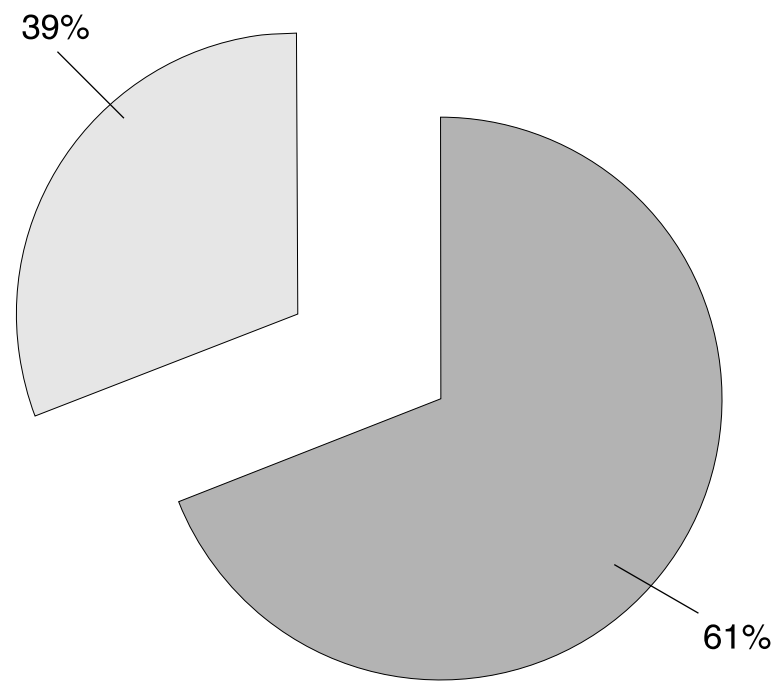

warsztaty korzystające

z komputera

warsztaty niekorzystające

z komputera

Źródło: opracowanie autorów na podstawie badań.

Z badań autorów tego artykułu wynika (ryc. 5), że 39\% małych warsztatów nie korzystało z komputera, prawdopodobnie go nie posiadało lub służył on innym celom. Niekiedy największym osiagnięciem w tym względzie było wystawianie faktur. Ci, którzy używali komputera, przede wszystkim wykorzystywali go do administrowania firmą i diagnostyki samochodów (ryc. 6). Tylko 18\% małych warsztatów miało własne strony internetowe i skrzynki pocztowe, i te warsztaty również korzystały z zasobów internetu. 
Podobne badania, lecz dotyczące wyłącznie posiadania przez warsztaty komputerów, przeprowadziły w Polsce Instytut GIPA i firma MotoFocus. Wynika z nich, że komputer posiadało $38 \%$ małych warsztatów, $57 \%$ średnich i 74\% dużych. Inaczej jest w warsztatach autoryzowanych - prawie wszystkie były wyposażone w komputery (98\%).

Ryc. 6. Sposoby wykorzystania komputera w małych warsztatach

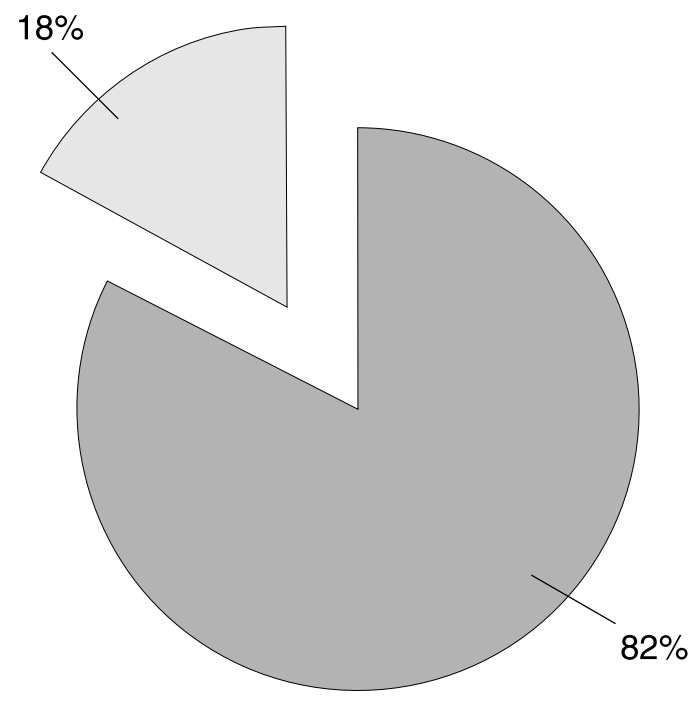

administrowanie firmą

i diagnostyka

samochodów

wirtualna współpraca

z klientami i dostawcami, aktywna strona internetowa

Źródło: opracowanie autorów na podstawie badań.

Trzeba jednak zastrzec, że przytaczane badania (autorów i GIPA) były prowadzone przed trzema laty. Obecnie te proporcje mogły ulec zmianie z powodu postępu w dziedzinie technologii informatycznych i zmian w świadomości przedsiębiorców w kwestii korzyści z powszechnego stosowania IT.

Ważnymi czynnikami wpływającymi na poziom przedsiębiorczości są doświadczenie przedsiębiorcy i tradycje rodzinne. Doświadczenie może być wyrażone latami działalności gospodarczej. Pielęgnowanie tradycji rodzinnych polega na przejęciu lub kontynuowaniu podobnej działalności ,z ojca na syna”. W usługach motoryzacyjnych zauważa się skłonność do pielęgnowania przedsiębiorczych tradycji rodzinnych i kontynuowania podobnej działalności przez następne pokolenie.

Właściciel małego warsztatu samochodowego to zwykle człowiek młody. W badanej próbie małych warsztatów najmłodszy właściciel miał 21 lat, a najstarszy - 71 lat. Średnia wieku wynosiła około 40 lat, przy czym 45\% właścicieli nie przekroczyło wieku 40 lat. 
Ryc. 7. Lata prowadzenia działalności gospodarczej przez właścicieli małych warsztatów samochodowych

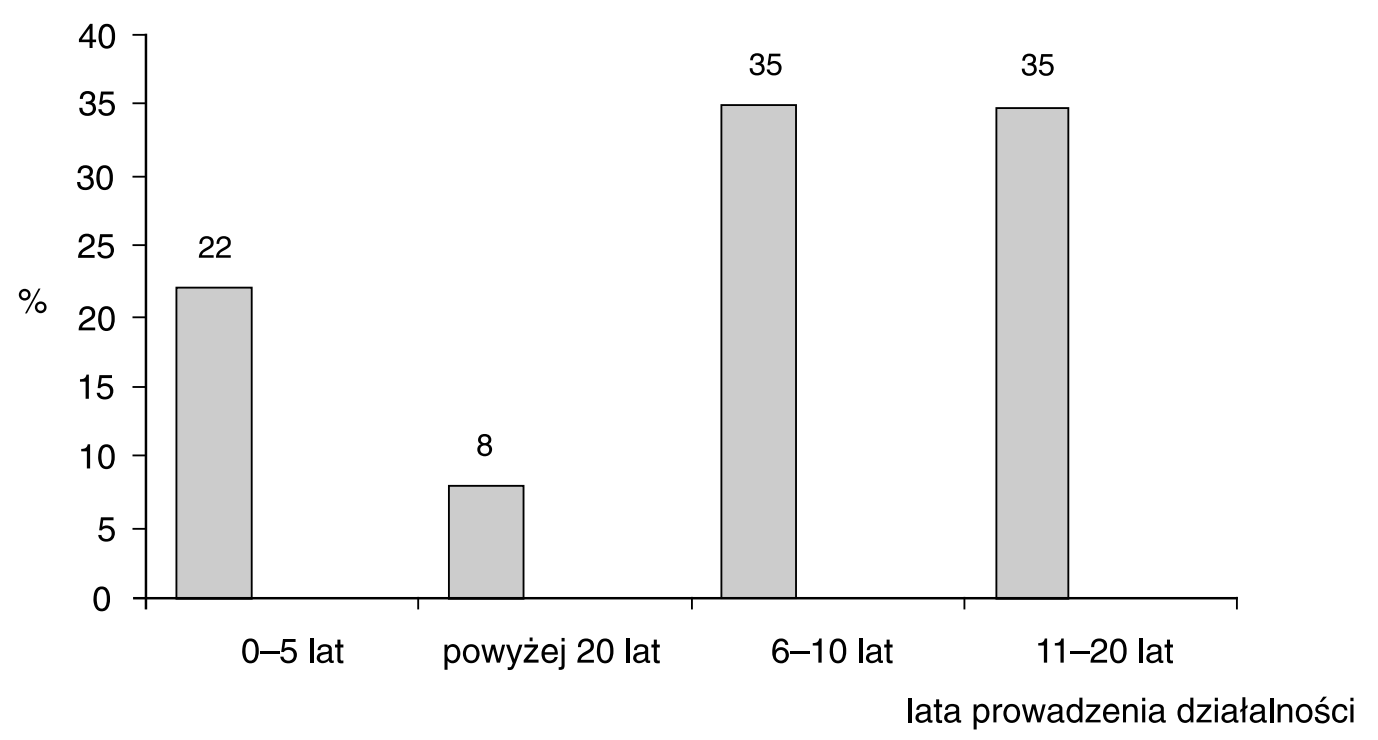

Źródło: opracowanie autorów na podstawie badań.

Właściciele warsztatów to osoby z dużym doświadczeniem w branży usług motoryzacyjnych, a jednocześnie w samodzielnym prowadzeniu działalności gospodarczej; $70 \% \mathrm{z}$ nich prowadziło działalność gospodarczą przez 5 do 20 lat i miało uznaną pozycję w branży. Nieliczna grupa (8\%) zajmowała się działalnościąjeszcze dłużej (ryc. 7). Zdecydowana większość (68\%) właścicieli nie wywodziła się z rodzin o tradycjach biznesowych; tylko $9 \%$ z nich przejęło warsztat od rodziny i nadal go prowadzi (ryc. 8).

Ryc. 8. Rodzina, z której pochodzi przedsiębiorca
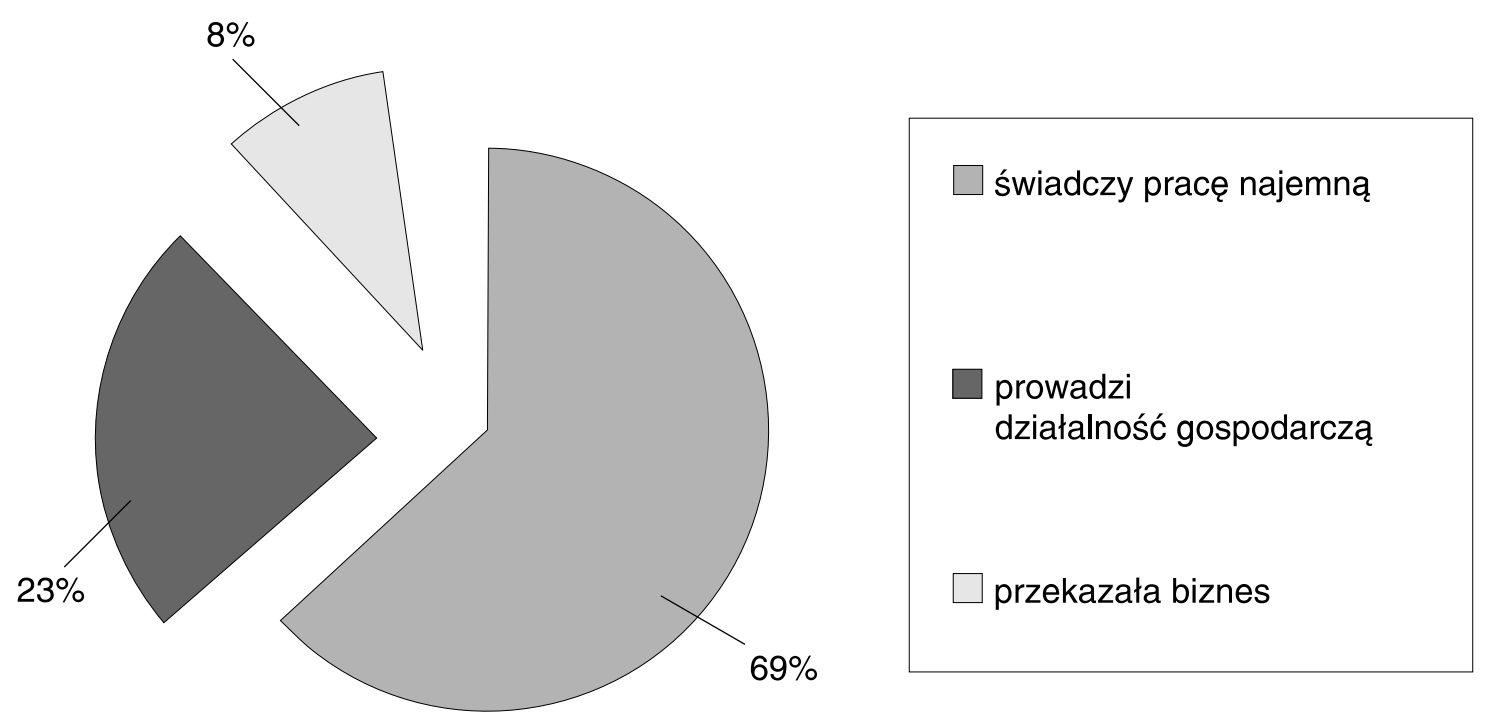

Źródło: opracowanie autorów na podstawie badań.

Należy zaznaczyć, że w polskich rodzinach w okresie przed transformacją systemu nie były kultywowane wzorce przedsiębiorczości zachęcające do prowadzenia samodzielnej działalności gospodarczej. Pewne tradycje przedsiębiorczości przeniesione zostały przez nieliczne grupy rzemieślników funkcjonujące w poprzednim systemie na obrzeżach gospodarki socjalistycznej. Wiele warsztatów powstało w połowie lat 80 . i na początku 90 . XX w. Dopiero od następców ich 
właścicieli będzie można oczekiwać procesów kształtowania świadomości przedsiębiorczej. Warto przytoczyć podsumowanie badań przedsiębiorców przeprowadzone w ramach ich nurtu biograficznego (Bławat 2003), z których wynika, że zawód ojca i wychowanie rodzinne są istotnymi czynnikami kształtującymi przedsiębiorczość.

\section{Podsumowanie}

Właściciele i personel małych warsztatów dokształcają się sporadycznie. Na zdobywanie wiedzy przeznaczają niewielkie środki i nie planują ich w swoich budżetach. Tylko kilka procent z nich uczęszcza na szkolenia, kursy. Bardzo rzadko uzupełniają swoją wiedzę na studiach podyplomowych.

Małe warsztaty w niedostatecznym stopniu wykorzystują możliwości komputera i internetu w celu podwyższania kwalifikacji. Niewielu z nich ma własne strony internetowe i skrzynki pocztowe.

Właściciel małego warsztatu to osoba z dużym doświadczeniem w branży usług motoryzacyjnych, przeważnie człowiek młody, zajmujący się wszystkimi sprawami firmy. Charakteryzują go cechy przedsiębiorcy „omnibusa” i ,rutyniarza”. Nie ma tradycji rodzinnych.

W przyszłości należy oczekiwać, że Polacy będą częściej korzystać z nowych samochodów. Samochody o wieku powyżej 10 lat będą kierowane do recyklingu. Przy takiej prognozie małe warsztaty powinny wykorzystać obecną koniunkturę i poprzez systematyczne zdobywanie nowych umiejętności starać się zdobyć przewagę konkurencyjną. Jest to najpewniejsza droga do utrzymania się na rynku. Nasilająca się konkurencja, ekspansja sieci warsztatowych, w tym i z Zachodu, oraz zmiana upodobań klientów mogą doprowadzić do spadku zainteresowania małymi warsztatami opierającymi się na przestarzałej wiedzy, technologii i urządzeniach oraz opinii złotej rączki. Zapewne nikt nie będzie chciał takiemu warsztatowi powierzyć współczesnego samochodu, którego obsługa czy naprawa wymaga wszechstronnej wiedzy i - niekiedy - warunków laboratoryjnych.

Należy podkreślić (co potwierdziły badania), że małe warsztaty, w których systematycznie śledzi się fachową prasę, nastawione na różnorodne formy zdobywania wiedzy, mogą pochwalić się dobrym wyposażeniem, szerokim wykorzystaniem komputera w diagnostyce i zarządzaniu, certyfikatami od dostawców, przynależnością do sieci lub zalążkiem takiej współpracy, a także znakomitym wyszkoleniem personelu. Są to warsztaty stale zdobywające wiedzę i opierające na niej swoją działalność.

Perspektywę rozwoju czy upadku niektórych małych warsztatów w najbliższym czasie trudno dokładnie przewidzieć ze względu na rozwój usług związany z poziomem zamożności obywateli. Z pewnością te warsztaty, które cechują: niskie natężenie działań przedsiębiorczych, brak świadomości konieczności doskonalenia się i bierne ,żeglowanie” po rynku, utracą klientów i będą musiały zrezygnować z napraw samochodów. Z badań autorów wynika, że może to dotyczyć około połowy małych warsztatów.

\section{Literatura}

1. Badanie kanałów dystrybucji, materiały niepublikowane, GIPA, grudzień 2003.

2. Bławat F., 2003, Przedsiębiorca w teorii przedsiębiorczości i praktyce małych firm, Gdańskie Towarzystwo Naukowe, Gdańsk.

3. Cichoń J., 2005, Wyposażenie i coś jeszcze, „Świat Motoryzacji”, 4/2005, s. 26.

4. Czaja I., 1999, Przedsiębiorca i działania przedsiębiorcze [w:] J. Targalski (red.) Przedsiębiorczość i rozwój firmy, Akademia Ekonomiczna w Krakowie, Kraków. 
5. Entrepreneurship a Candidate's Guide, National Commission on Entrepreneurship an Initiative of the Kauffman Center for Entrepreneurial Leadership at the Ewning Marion Kauffman Foundation, August 2002, www.ncoe.org, 4249_ncoe_guj, 2003.03.30.

6. Janczewski J., 2005, Kryteria i miary oceny przedsiębiorczości małej firmy [w:] Z. Zioło, T. Rachwał (red.), Przedsiębiorczość a współczesne wyzwania cywilizacyjne, Przedsiębiorczość - Edukacja nr 1, Wydawnictwo „MiWa”, Akademia Pedagogiczna im. Komisji Edukacji Narodowej w Krakowie, Kraków, s. 115-120.

\section{Knowledge in the Entrepreneurial Activity in Small Automotive Services}

Growing number of second hand cars imported to Poland caused fast development of the automotive services occurring mainly in the small enterprises. New knowledge and advanced technical equipment were required for satisfactory level of service. The main factors causing the need of change in the behavior and activity of entrepreneurs have been discussed here. 